Working Paper No. 03/04

\title{
Regional GDP in Britain, 1871-1911: Some Estimates
}

Nicholas F. R. Crafts

(C) Nicholas F. R. Crafts

Department of Economic History

London School of Economics 
This project is funded by the ESRC under grant 2394/R000239536, "Large-Scale Technological Change", and is directed by Professor N.F.R. Crafts.

For further details about this project and additional copies of this, and other papers in the series, go to:

http://www.Ise.ac.uk/collection/economichistory/

Department of Economic History

London School of Economics

Houghton Street

London, WC2A 2AE

Tel: $\quad$ +44 (0) 2079557860

Fax: $\quad$ +44 (0) 2079557730 


\title{
Regional GDP In Britain, 1871-1911: Some Estimates*
}

Nicholas F. R. Crafts

\begin{abstract}
The paper builds on a method proposed by Geary and Stark (2002) for estimating regional incomes in Victorian Britain. This is modified by using tax data to allocate non-wage income across regions. The results suggest that the coefficient of variation of regional GDP per head was rising rapidly prior to World War I in similar fashion to the late twentieth century such that its level in 1911 and 2001 was about the same. In both episodes of globalization there were big winners and big losers among British regions.
\end{abstract}

JEL Classifications: N23; R11

\section{Introduction}

A recent paper by Geary and Stark (2002) offers a method of allocating GDP across British regions using information on relative wages and sectoral shares of employment. They use this to estimate GDP for England, Ireland, Scotland and Wales for the census years from 1861 through 1911. A natural extension of this approach is to estimate GDP for the standard English administrative regions established in 1974 on a similar basis. This is carried out in section II below.

The results obtained are compared with the regional distribution of income tax assessments in section III. These show a different pattern and, in particular, attribute a higher proportion of taxable income to London. In this period, income tax was effectively levied only on nonwage incomes. This suggests a refinement of the Geary-Stark method in

\footnotetext{
* I have gained from helpful comments from Dudley Baines, Steve Broadberry, Tim Leunig, Brian Mitchell, Abay Mulatu and Jim Taylor. Frank Geary generously made data available to me. The usual disclaimer applies.
} 
which their procedure is retained for wage income but the non-wage share of GDP is allocated across regions on the basis of the tax returns. The results are also shown in section III.

These estimates permit a comparison of changes in regional income inequality during two episodes of globalization, in the late nineteenth and late twentieth centuries, in Section IV. Two specific questions are addressed:

1) Was regional GDP per person less equally distributed prior to World War I than in the recent past?

2) How do recent trends in regional income disparities compare with those of a century ago?

Section V concludes.

\section{Implementing The Geary-Stark Method For English Regions}

Geary and Stark (2002) base their estimates of country GDP on data on the structure of employment (agriculture, industry, services) and sectoral wages together with data for UK output for each sector. They assume that regional sectoral productivity relative to the UK average is reflected in sectoral regional wages relative to the UK average. There are no adequate data for service sector wages which are taken to be equal to a weighted average of agricultural and industrial wages. Agricultural wages are available directly while industry is based on estimates for construction and shipbuilding \& engineering. 
UK GDP is defined as

$$
Y_{U K}=\Sigma Y_{i}
$$

where $Y_{i}$ is GDP of country $i$ which is in turn defined as

$$
Y_{i}=\Sigma y_{i j} L_{i j}
$$

where $y_{i j}$ is average value-added per worker in country $i$ in industry $j$ and $\mathrm{L}_{\mathrm{ij}}$ is the corresponding number of workers.

Assume that

$Y_{i}=\Sigma\left[y_{j} \beta_{j}\left(w_{i j} / w_{j}\right)\right] L_{i j}$

where $w_{i j}$ is the wage paid in country $i$ in industry $j$ and $w_{j}$ is the national average wage in industry $j . \beta$ is a scalar which preserves the relative country differences but scales the absolute levels so that country totals for each industry sum to the known UK total. The data required to implement this procedure are agricultural and industrial wages by region and a breakdown of employment by region into agricultural, industrial and service-sector components.

Geary and Stark (2002) give estimates for Ireland, Scotland and Wales for each census year from 1871 to 1911 . These have been accepted for use in Table 1 and the task is then to allocate English GDP among its regions following the method set out above. Employment data are available in Lee (1979) for standard administrative regions as defined in 1974 and Greater London (London and Middlesex) can be separated from the rest of the South East. Agricultural wages can be obtained from 
Bowley (1898) for 1871 through 1891, for 1901 from Hunt (1973) and for 1911 from the Abstract of Labour Statistics (PP 1912/13).

Industry wages for the English regions are probably best approximated using evidence from the building sector (Hunt, 1973). This can be done using the ample evidence in the Earnings and Hours Inquiries for the years from 1881 through 1911 (PP 1893/4, vol 83; PP 1910, vol. 84). 1871, for which less information is available, can be based on building sector wages for principal towns reported in Board of Trade (1908). The resulting shares of UK GDP and estimates of GDP at current prices are reported in Table 1.

\section{Taking Account Of The Income Tax Returns}

Earlier discussions of regional income inequality were based on the evidence of returns of amounts assessed for taxation. Lee argued that these showed an enormous gap between the Home Counties and the rest of the country and, based on Inhabited House Duty his table of relative income per head showed the South East with income 3.31 times the level of the North West (1986, p.131). Rubinstein (1987) was more cautious but claimed that the income tax returns were a good guide to middle class incomes and, in this regard, noted a surge in the relative position of London after 1880 that is not apparent in Table 1.

In essence, Table 1 is based on information relating to the distribution of wage income across regions whereas the income tax data of this period relate to non-wage incomes. It seems important to take account of the information in the tax returns but inappropriate to use them to the exclusion of wage data. This suggests that the Geary-Stark method is retained for the distribution of the wages component of GDP 
but the income tax data are used to account for the remainder with an equal weight for each, i.e. averaging the two estimates. ${ }^{1}$

For the purposes of estimating regional income assessments for income tax under schedules $A, B$ and $D$ which taxed earnings from the ownership of property, farmers' income, and business and professional profits, respectively, can be used. In each year the 50 per cent of GDP accruing to non-wage income is divided into property income and profits according to the ratio of assessments under $(A+B)$ and under $D$. Regional shares of each category are calculated and from this a regional share of total non-wage income is obtained. The main problem in this is income under Schedule D which was rapidly increasing in relative importance and of which London accounted for a large and rapidly increasing proportion.

It seems clear that this is to some extent a statistical artefact and reflects taxes assessed on the head offices of companies that earned profits in the provinces (Rubinstein, 1987, pp. 103-6). The only way to correct for this appears to be to use the breakdown of receipts under Schedule D divided into those from 'individuals and firms' and those from 'companies and local authorities' published by the Inland Revenue for one year only, 1949-50. These show for the South East (London was not shown separately) a much smaller share in the former category than for any other region. Accordingly, the allocation of Schedule D assessments across regions is based on the raw data adjusted for the proportion of receipts from individuals and firms in 1949/50. Table 2 shows the resulting regional distribution of income tax assessments which are to be used for the regional allocation of non-wage income. ${ }^{2}$

\footnotetext{
${ }^{1}$ Between 1870/9 and 1905/14 wages and salaries as a share of GDP varied between 47.2 and 48.7 per cent according to the estimates in Deane and Cole (1962, p. 247). ${ }^{2} \mathrm{~A}$ check on the reasonableness of these alternative procedures may be obtained by examining their implications for the growth of real incomes per head for the (most sensitive) London region for 1911 to $1954 / 5$ using the Inland Revenue's income census
} 
Table 3 reports best guess estimates of regional incomes on the basis of using the Geary-Stark method for wage income and the tax assessments as allocated in Table 2 for non-wage income. The results are similar to those obtained using the Geary-Stark method in Table 1 for 1871 but by 1911 the share of GDP attributed to London is almost 4 percentage points higher than in Table 1 and to all other regions is lower, in several cases by around 1 percentage point.

\section{Regional Income Inequality}

Combining the estimates in Table 3 with population estimates from the Census reported in Lee (1979) allows the comparison of regional GDP per person reported in Table 4. This exhibits a number of interesting features. First, London had a very large and increasing lead over the rest of the country. Second, the heartlands of the industrial revolution, notably the North West, were already in relative economic decline. Third, the arable agricultural region of East Anglia suffered a marked deterioration in its relative position.

The other striking result in Table 4 is that the coefficient of variation was increasing between 1871 and 1911. The proximate reason for this was the increasing regional inequality in the non-wage component of GDP since Geary-Stark estimates show no such tendency. In turn, as far as the tax returns are concerned, during 1871 to 1911 Schedule $A$ income (property) diminished in importance relative to Schedule $D$ income (profits) while London took a rapidly increasing share of the latter.

for that year. Using unadjusted tax receipts alone to estimate 1911 income per head implies a growth rate of -0.58 per cent per year over this period, using unadjusted tax and wages with $50 / 50$ weights implies 0.08 per cent per year while incorporating the head offices adjustment implies 0.58 per cent per year. The first of these seems highly implausible and this suggests that the view of pre-1914 regional inequality in Lee (1986) is much exaggerated. The last is not unreasonable given the adverse trends in rentier and profit incomes over the period. 
Table 5 reports estimates of regional GDP per person based on official sources for the same regions a century later. These are, of course, directly estimated rather than based on the indirect methods used for the earlier period. ${ }^{3}$ However, Geary and Stark (2002, p. 921) show that their method replicates 1971 regional incomes very well and the following comparisons of the recent past with the late Victorian/Edwardian economy are unlikely to be misleading. Indeed, some interesting differences stand out. First, in the late twentieth century London was still the region with the highest level of GDP per person but its lead was much less. Second, although there were notable losers in the years of deindustrialization in the late twentieth century, namely, North, North West and West Midlands, no region was hit anywhere near as badly as was East Anglia in the late nineteenth century. Third, East Anglia and the Rest of the South East have made strong progress in recent decades and by 2001 their income per head relative to the British average was much higher than in the decades before pre-World War I. Fourth, the recent past has seen a clear North-South divide within England whereas a century ago the contrast in fortunes was between London and the rest of England.

Despite these contrasts, there is also a striking similarity in these regional experiences. The coefficient of variation of regional GDP per person was rising rapidly in both periods. ${ }^{4}$ In 2001 the coefficient of variation was quite similar to 1911 and about twice that of 1971 which, in turn, was a little below the 1871 level.

\footnotetext{
${ }^{3}$ Recent revisions to regional GDP estimates have been published on the Office of National Statistics Website but not yet in Regional Trends. The website publication (Cope et al., 2003) incorporates the corrections made to estimates published in 2002 but subsequently withdrawn after errors were discovered.

${ }^{4}$ If the head-office adjustment is not made to the Schedule $D$ assessments, the coefficient of variation of regional incomes per head rises from 0.150 in 1871 to 0.219 in 1911. If the Geary-Stark-type estimates with no correction for the evidence of the tax returns are used, however, the coefficient of variation falls from 0.146 in 1871 to 0.112 in 1911.
} 
Table 6 reports the regional rates of growth implied by comparison of the estimates of levels of GDP per person based on the use of the national GDP deflator to convert current price estimates into constant prices for all regions. This offers a reality check through the growth rates derived for 1911 to $1954 / 5$. There is a plausible spread around the national average of 1.13 per cent per year with the West Midlands showing the strongest growth and London, Scotland and Wales the weakest. The results could be described in terms of the conventional wisdom of "a wealthy and prosperous south against a poor and declining north" (Lee, 1986, p. 268).

At the same time, this picture clearly needs to be qualified. Real GDP growth between 1911 and 1954/5 is indeed shown as lower (higher) than for the 1871 to 1911 period in Outer (Inner) Britain. However, apart from Scotland, all regions outside the South East seem to have experienced a stronger rate of growth of real GDP per person in the second period and the region with the next lowest growth in real GDP per person between 1911 and 1954/5 was the South East. ${ }^{5}$

\section{Conclusions}

The estimates for regional GDP constructed in this paper support the following conclusions.

1) The inequality of regional GDP per person was much higher in the early twentieth century than in the long boom after World War II but similar to the late twentieth century.

\footnotetext{
${ }^{5}$ Despite the overview in Lee (1986, p.268) quoted above, his own account of regional income differentials implies a much stronger version of this outcome for the South East as a comparison of his Tables 7.3 and 14.1 reveals.
} 
2) Both periods of globalization saw rapidly increasing disparities in regional GDP per person.

Regional divergence in pre World War I UK was driven by globalization which reduced rents from agricultural land and increased incomes from urban commerce. These years include the 'so-called' agricultural depression when arable farming was exposed to increasing imports from the New World as transport costs fell dramatically. Agriculture's share of output and employment contracted rapidly. By contrast, British invisibles flourished and underpinned the share of industrial and commercial profits in national income. Similarly, the globalization of recent decades has promoted de-industrialization in the midlands and north of England while favouring the growth of business and financial services in the south-east. The striking conclusion is that both episodes of globalization have been associated with major changes in regional income differentials in Britain with big losers and big winners. 
Table 1. Geary-Stark Regional GDP, 1871-1911, £mn (\%)

\begin{tabular}{|c|c|c|c|c|c|}
\hline UK & $\begin{array}{l}1871 \\
1208 \\
(100)\end{array}$ & $\begin{array}{l}1881 \\
1307 \\
(100)\end{array}$ & $\begin{array}{l}1891 \\
1495 \\
(100)\end{array}$ & $\begin{array}{l}1901 \\
2049 \\
(100)\end{array}$ & $\begin{array}{l}1911 \\
2330 \\
(100)\end{array}$ \\
\hline London & $\begin{array}{l}200.5 \\
(16.6)\end{array}$ & $\begin{array}{l}232.6 \\
(17.8)\end{array}$ & $\begin{array}{l}264.6 \\
(17.7)\end{array}$ & $\begin{array}{l}372.9 \\
(18.2)\end{array}$ & $\begin{array}{l}416.0 \\
(17.9)\end{array}$ \\
\hline Rest South East & $\begin{array}{l}131.7 \\
(10.9)\end{array}$ & $\begin{array}{l}132.0 \\
(10.1)\end{array}$ & $\begin{array}{l}158.5 \\
(10.6)\end{array}$ & $\begin{array}{l}252.0 \\
(12.3)\end{array}$ & $\begin{array}{l}313.8 \\
(13.5)\end{array}$ \\
\hline East Anglia & $\begin{array}{l}32.6 \\
(2.7)\end{array}$ & $\begin{array}{l}30.1 \\
(2.3)\end{array}$ & $\begin{array}{l}31.4 \\
(2.1)\end{array}$ & $\begin{array}{l}43.0 \\
(2.1)\end{array}$ & $\begin{array}{l}48.8 \\
(2.1)\end{array}$ \\
\hline South West & $\begin{array}{l}73.7 \\
(6.1)\end{array}$ & $\begin{array}{l}78.4 \\
(6.0)\end{array}$ & $\begin{array}{l}77.7 \\
(5.2)\end{array}$ & $\begin{array}{r}106.5 \\
(5.2)\end{array}$ & $\begin{array}{r}120.9 \\
(5.2)\end{array}$ \\
\hline West Midlands & $\begin{array}{l}77.3 \\
(6.4)\end{array}$ & $\begin{array}{l}86.3 \\
(6.6)\end{array}$ & $\begin{array}{l}97.2 \\
(6.5)\end{array}$ & $\begin{array}{r}137.3 \\
(6.7)\end{array}$ & $\begin{array}{r}158.0 \\
(6.8)\end{array}$ \\
\hline East Midlands & $\begin{array}{l}62.8 \\
(5.2)\end{array}$ & $\begin{array}{l}68.0 \\
(5.2)\end{array}$ & $\begin{array}{l}82.2 \\
(5.5)\end{array}$ & $\begin{array}{r}110.6 \\
(5.4)\end{array}$ & $\begin{array}{r}130.2 \\
(5.6)\end{array}$ \\
\hline North West & $\begin{array}{l}169.1 \\
(14.0)\end{array}$ & $\begin{array}{l}189.5 \\
(14.5)\end{array}$ & $\begin{array}{l}221.3 \\
(14.8)\end{array}$ & $\begin{array}{l}282.8 \\
(13.8)\end{array}$ & $\begin{array}{l}323.1 \\
(13.9)\end{array}$ \\
\hline Yorks \& Humb & $\begin{array}{l}88.2 \\
(7.3)\end{array}$ & $\begin{array}{r}100.6 \\
(7.7)\end{array}$ & $\begin{array}{r}121.1 \\
(8.1)\end{array}$ & $\begin{array}{r}159.8 \\
(7.8)\end{array}$ & $\begin{array}{r}185.9 \\
(8.0)\end{array}$ \\
\hline North & $\begin{array}{l}65.2 \\
(5.4)\end{array}$ & $\begin{array}{l}70.6 \\
(5.4)\end{array}$ & $\begin{array}{l}86.7 \\
(5.8)\end{array}$ & $\begin{array}{r}114.7 \\
(5.6)\end{array}$ & $\begin{array}{r}130.2 \\
(5.6)\end{array}$ \\
\hline Wales & $\begin{array}{l}55.6 \\
(4.6)\end{array}$ & $\begin{array}{l}60.1 \\
(4.6)\end{array}$ & $\begin{array}{l}71.8 \\
(4.8)\end{array}$ & $\begin{array}{l}94.3 \\
(4.6)\end{array}$ & $\begin{array}{r}116.5 \\
(5.0)\end{array}$ \\
\hline Scotland & $\begin{array}{l}120.8 \\
(10.0)\end{array}$ & $\begin{array}{l}133.3 \\
(10.2)\end{array}$ & $\begin{array}{l}157.0 \\
(10.5)\end{array}$ & $\begin{array}{l}225.4 \\
(11.0)\end{array}$ & $\begin{array}{l}240.0 \\
(10.3)\end{array}$ \\
\hline Ireland & $\begin{array}{l}129.3 \\
(10.7)\end{array}$ & $\begin{array}{r}126.8 \\
(9.7)\end{array}$ & $\begin{array}{r}125.6 \\
(8.4)\end{array}$ & $\begin{array}{r}149.6 \\
(7.3)\end{array}$ & $\begin{array}{r}146.8 \\
(6.3)\end{array}$ \\
\hline
\end{tabular}

Source: derived as explained in the text; nominal UK GDP from Mitchell (1988, pp. 832-3). 
Table 2. Regional Shares of British Income Tax Assessments, 1871-1911

$\begin{array}{lrrrrr} & \mathbf{1 8 7 1} & \mathbf{1 8 8 1} & \mathbf{1 8 9 1} & \mathbf{1 9 0 1} & \mathbf{1 9 1 1} \\ \text { London }^{\mathrm{a}} & 19.15 & 19.57 & 24.27 & 25.00 & 26.76 \\ \text { Rest South } & 12.51 & 12.42 & 11.39 & 11.14 & 11.22 \\ \text { East } & & & & & \\ \text { East Anglia } & 4.52 & 3.88 & 3.04 & 2.27 & 2.08 \\ \text { South West } & 9.03 & 8.14 & 6.96 & 5.85 & 5.93 \\ \text { West Midlands } & 7.14 & 6.92 & 5.89 & 5.95 & 5.34 \\ \text { East Midlands } & 7.47 & 7.19 & 6.34 & 5.98 & 6.01 \\ \text { North West } & 11.49 & 12.16 & 12.25 & 12.71 & 12.44 \\ \text { Yorks \& Humb } & 7.22 & 7.49 & 7.21 & 7.55 & 7.09 \\ \text { North } & 5.33 & 5.24 & 5.15 & 5.17 & 4.96 \\ \text { Wales }_{\text {Scotland }}^{b} & 4.37 & 4.51 & 5.09 & 4.90 & 5.34 \\ & 11.76 & 12.59 & 12.40 & 13.49 & 12.83\end{array}$

Source: derived from Rubinstein (1987) and British Parliamentary Papers, 1870 vol XLI, 1882 vol XXXVII, 1896 vol XLIX, 1901 vol XVIII, 1912/13 vol $X$ LIX. Income tax comprises assessments under Schedules A, B, and D. The Schedule $D$ assessments are adjusted according to the proportion of receipts accruing to 'individuals and firms' as opposed to 'companies and local authorities', see text.

Notes:

a. London is taken to be the sum of Middlesex and Surrey.

b. North (Yorkshire \& Humberside) is underestimated (overestimated) because Yorkshire North Riding is included in the global total for Yorkshire. 
Table 3. Best Guess Regional GDP, 1861-1911, $£$ mn (\%)

\begin{tabular}{|c|c|c|c|c|c|}
\hline & 1871 & 1881 & 1891 & 1901 & 1911 \\
\hline UK & $\begin{array}{l}1208 \\
(100)\end{array}$ & $\begin{array}{l}1307 \\
(100)\end{array}$ & $\begin{array}{l}1495 \\
(100)\end{array}$ & $\begin{array}{l}2049 \\
(100)\end{array}$ & $\begin{array}{l}2330 \\
(100)\end{array}$ \\
\hline London & $\begin{array}{l}203.7 \\
(16.9)\end{array}$ & $\begin{array}{l}231.8 \\
(17.7)\end{array}$ & $\begin{array}{l}298.4 \\
(20.0)\end{array}$ & $\begin{array}{l}423.9 \\
(20.7)\end{array}$ & $\begin{array}{l}500.0 \\
(21.5)\end{array}$ \\
\hline Rest South East & $\begin{array}{l}133.4 \\
(11.0)\end{array}$ & $\begin{array}{l}139.3 \\
(10.7)\end{array}$ & $\begin{array}{l}157.2 \\
(10.5)\end{array}$ & $\begin{array}{l}231.8 \\
(11.3)\end{array}$ & $\begin{array}{l}279.3 \\
(12.0)\end{array}$ \\
\hline East Anglia & $\begin{array}{l}40.7 \\
(3.4)\end{array}$ & $\begin{array}{l}38.0 \\
(2.9)\end{array}$ & $\begin{array}{l}36.5 \\
(2.4)\end{array}$ & $\begin{array}{l}43.0 \\
(2.1)\end{array}$ & $\begin{array}{l}47.1 \\
(2.0)\end{array}$ \\
\hline South West & $\begin{array}{l}85.7 \\
(7.1)\end{array}$ & $\begin{array}{l}87.2 \\
(6.7)\end{array}$ & $\begin{array}{l}86.5 \\
(5.8)\end{array}$ & $\begin{array}{r}108.8 \\
(5.3)\end{array}$ & $\begin{array}{r}125.2 \\
(5.4)\end{array}$ \\
\hline West Midlands & $\begin{array}{l}77.2 \\
(6.4)\end{array}$ & $\begin{array}{l}84.0 \\
(6.4)\end{array}$ & $\begin{array}{l}89.0 \\
(6.0)\end{array}$ & $\begin{array}{r}125.2 \\
(6.1)\end{array}$ & $\begin{array}{r}137.3 \\
(5.9)\end{array}$ \\
\hline East Midlands & $\begin{array}{l}71.7 \\
(5.9)\end{array}$ & $\begin{array}{l}76.4 \\
(5.8)\end{array}$ & $\begin{array}{l}84.5 \\
(5.7)\end{array}$ & $\begin{array}{r}112.1 \\
(5.5)\end{array}$ & $\begin{array}{r}130.7 \\
(5.6)\end{array}$ \\
\hline North West & $\begin{array}{l}146.6 \\
(12.1)\end{array}$ & $\begin{array}{l}166.5 \\
(12.7)\end{array}$ & $\begin{array}{l}194.6 \\
(13.0)\end{array}$ & $\begin{array}{l}262.1 \\
(12.8)\end{array}$ & $\begin{array}{l}297.4 \\
(12.8)\end{array}$ \\
\hline Yorks \& Humb & $\begin{array}{l}83.0 \\
(6.9)\end{array}$ & $\begin{array}{l}94.5 \\
(7.2)\end{array}$ & $\begin{array}{r}109.9 \\
(7.4)\end{array}$ & $\begin{array}{r}151.6 \\
(7.4)\end{array}$ & $\begin{array}{r}170.4 \\
(7.3)\end{array}$ \\
\hline North & $\begin{array}{l}61.4 \\
(5.1)\end{array}$ & $\begin{array}{l}66.2 \\
(5.1)\end{array}$ & $\begin{array}{l}78.6 \\
(5.3)\end{array}$ & $\begin{array}{r}106.4 \\
(5.2)\end{array}$ & $\begin{array}{r}119.2 \\
(5.1)\end{array}$ \\
\hline Wales & $\begin{array}{l}51.4 \\
(4.3)\end{array}$ & $\begin{array}{l}56.6 \\
(4.3)\end{array}$ & $\begin{array}{l}70.8 \\
(4.7)\end{array}$ & $\begin{array}{l}93.7 \\
(4.6)\end{array}$ & $\begin{array}{r}116.6 \\
(5.0)\end{array}$ \\
\hline Scotland & $\begin{array}{l}123.9 \\
(10.3)\end{array}$ & $\begin{array}{l}141.0 \\
(10.8)\end{array}$ & $\begin{array}{l}163.4 \\
(10.9)\end{array}$ & $\begin{array}{l}240.8 \\
(11.8)\end{array}$ & $\begin{array}{l}260.0 \\
(11.2)\end{array}$ \\
\hline Ireland & $\begin{array}{l}129.3 \\
(10.7)\end{array}$ & $\begin{array}{r}126.8 \\
(9.7)\end{array}$ & $\begin{array}{r}125.6 \\
(8.4)\end{array}$ & $\begin{array}{r}149.6 \\
(7.3)\end{array}$ & $\begin{array}{r}146.8 \\
(6.3)\end{array}$ \\
\hline
\end{tabular}

Sources: derived from Tables 1 and 2. Ireland: Geary-Stark estimates in Table 1; others except $\mathrm{YH}$ and North are average of tax and Geary Stark proportions. $\mathrm{YH}$ and North this average is redistributed between the two regions on the basis of relative Geary-Stark GDP in YH and North. 
Table 4. Regional GDP/Person (Britain = 100)

$\begin{array}{lrrrrr} & \mathbf{1 8 7 1} & \mathbf{1 8 8 1} & \mathbf{1 8 9 1} & \mathbf{1 9 0 1} & \mathbf{1 9 1 1} \\ \text { South East } & 115.2 & 117.8 & 120.1 & 121.7 & 124.6 \\ \quad \text { London } & 141.9 & 139.0 & 150.4 & 154.9 & 165.6 \\ \quad \text { Rest of SE } & 89.5 & 93.9 & 86.9 & 87.4 & 86.3 \\ \text { East Anglia } & 97.0 & 92.3 & 83.0 & 76.9 & 76.8 \\ \text { South West } & 88.6 & 92.1 & 84.9 & 81.5 & 85.7 \\ \text { West Midlands } & 84.8 & 84.5 & 79.6 & 81.7 & 78.4 \\ \text { East Midlands } & 106.2 & 100.4 & 96.4 & 90.3 & 90.6 \\ \text { North West } & 106.0 & 102.0 & 100.6 & 97.9 & 97.2 \\ \text { Yorks \& Humb. } & 94.1 & 92.9 & 92.6 & 91.9 & 89.5 \\ \text { North } & 91.3 & 85.1 & 85.4 & 82.9 & 79.2 \\ \text { Wales } & 88.6 & 90.3 & 96.2 & 90.7 & 90.1 \\ \text { Scotland } & 90.4 & 95.0 & 97.9 & 104.9 & 102.1 \\ & & & & & \\ \text { CV } & 0.097 & 0.097 & 0.119 & 0.138 & 0.148\end{array}$

Source: derived from Table 3 and population data in Lee (1979). CV calculation treats South East as one observation and does not include London and Rest of South East as separate regions. 
Table 5. Regional GDP/Person, 1954/5-91 (Britain = 100)

South East

London

Rest of South East

East Anglia

South West

West Midlands

East Midlands

North West

Yorks \& Humberside

North

Wales

Scotland

CV

$\begin{array}{rrrrr}\mathbf{1 9 5 4 / 5} & \mathbf{1 9 7 1} & \mathbf{1 9 8 1} & \mathbf{1 9 9 1} & \mathbf{2 0 0 1} \\ \mathbf{1 1 2 . 7} & 112.7 & 115.5 & 118.9 & 126.1 \\ 137.6 & 123.4 & 126.0 & 129.4 & 133.9 \\ 97.9 & 104.6 & 108.4 & 109.5 & 119.0 \\ 83.5 & 92.8 & 94.7 & 108.9 & 109.1 \\ 86.4 & 93.9 & 91.8 & 92.4 & 88.4 \\ 107.9 & 101.9 & 89.1 & 91.3 & 89.7 \\ 101.6 & 95.7 & 95.6 & 94.4 & 91.0 \\ 97.8 & 95.3 & 92.9 & 90.2 & 89.3 \\ 98.4 & 92.5 & 90.2 & 89.5 & 85.5 \\ 88.0 & 86.1 & 92.2 & 83.1 & 75.6 \\ 82.0 & 87.5 & 82.0 & 82.8 & 78.2 \\ 88.1 & 92.2 & 94.8 & 98.9 & 93.7 \\ & & & & \\ 0.106 & 0.076 & 0.086 & 0.113 & 0.152\end{array}$

Source: for 1954/5, Annual Report of the Commissioners of the Inland Revenue, Cd. 341 (1958), for 1971 and 1981, Regional Trends and for 1991 and 2001, Cope et al. (2003). 
Table 6. Rates of Growth (\% per year)

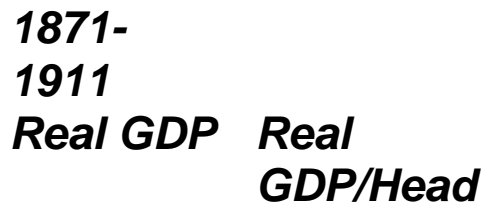

$1911-$

1954/5

Real GDP Real

GDP/Head

South East

London

Rest of South East

East Anglia

South West

West Midlands

East Midlands

North West

Yorks \& Humb

North

Wales

Scotland
2.19

2.33

1.94

0.44

1.04

1.53

1.59

1.86

1.89

1.75

2.14

1.95
0.96

1.14

0.67

0.16

0.68

0.56

0.36

0.54

0.63

0.40

0.80

1.06
1.42

0.56

2.44

1.57

1.54

2.54

1.92

1.32

1.61

1.55

0.98

0.84
0.78

0.58

1.32

1.22

1.05

1.77

1.29

1.04

1.25

1.27

0.80

0.67

Source: derived from estimates underlying Tables 4 and 5 assuming that price inflation was in each case at the rate of the national GDP deflator. 


\section{$\underline{\text { References }}$}

Board of Trade (1908), Rates of Wages and Hours of Wages in Various Industries in the United Kingdom for Various Years, unpublished microfilm in LSE library.

Bowley, A. L. (1898). The statistics of wages in the United Kingdom during the last hundred years: (part I) agricultural wages. Journal of the Royal Statistical Society, 61, pp. 702-722.

Bowley, A. L. (1901). The statistics of wages in the United Kingdom during the last hundred years: (Part VIII) wages in the building trades - concluded. Journal of the Royal Statistical Society, 64, pp. 102112.

Cope, I, Vincent, D., Marais, J. and Lucas, P. (2003). Regional gross value added. at www.statistics.gov.uk.

Deane, P. and Cole, W. A. (1962). British Economic Growth, 1688-1959. Cambridge: Cambridge University Press.

Geary, F. and Stark, T. (2002). Examining Ireland's post-famine economic growth performance. Economic Journal, 112, pp. 919-935.

Hunt, E. H. (1973). Regional Wage Variations in Britain, 1850-1914. Oxford: Clarendon Press.

Lee, C. H. (1979). British Regional Employment Statistics, 1841-1971. Cambridge: Cambridge University Press.

Lee, C. H. (1986). The British Economy since 1700: a Macroeconomic Perspective. Cambridge: Cambridge University Press.

Mitchell, B. R. (1988). British Historical Statistics. Cambridge: Cambridge University Press.

Rubinstein, W. D. (1987). Elites and the Wealthy in Modern British History. New York: St Martin's Press. 


\section{LONDON SCHOOL OF ECONOMICS}

\section{DEPARTMENT OF ECONOMIC HISTORY}

\section{WORKING PAPERS IN LARGE-SCALE TECHNOLOGICAL CHANGE}

For further copies of this, and to see other titles in the department's group of working paper series, visit our website at:

http://www.Ise.ac.uk/collections/economichistory/

01/04: $\quad$ Steam as a General Purpose Technology: A Growth Accounting Perspective Nicholas F.R. Crafts

(First published as 75/03 in the Department of Economic History Working Papers Series).

02/04: Quantifying the Contribution of Technological Change to Economic Growth in Different Eras: A Review of the Evidence

Nicholas F.R. Crafts

(First published as 79/03 in the Department of Economic History Working Papers Series).

03/04: $\quad$ Regional GDP in Britain, 1871-1911: Some Estimates Nicholas F.R. Crafts 